\title{
Right, Crime, and Court: Toward a Unifying Political Conception of International Law
}

\author{
Alain Zysset ${ }^{1}$ \\ Published online: 16 November 2017 \\ (C) The Author(s) 2017. This article is an open access publication
}

\begin{abstract}
It is widely acknowledged that human rights law (hereafter, HRL) and international criminal law (hereafter, ICL) share core normative features. Yet, the literature has not yet reconstructed this underlying basis in a systematic way. In this contribution, I lay down the basis of such an account. I first identify a similar tension between a "moral" and a "political" approach to the normative foundations of those norms and to the legitimate role of international courts (hereafter, ICs) and tribunals adjudicating those norms. With a view to bring the debate forward, I then turn to the practices of HRL and international criminal law (hereafter, ICL) to examine which of those approaches best illuminates some salient aspects of the adjudication of ICs. Finally, I argue that the political approach best explains the practice. While each preserves a distinct role, HRL and ICL both establish the basic conditions for the primary subject of international law (HRL and ICL, for the purpose of this article), namely the state, to legitimately govern its own subjects constructed as free and equal moral agents.
\end{abstract}

Keywords International law $\cdot$ Human rights law $\cdot$ International criminal law $\cdot$ Human rights theory $\cdot$ Criminal law theory

\section{Introduction}

Two conceptions of the law's appropriate content and justification have polarized the debate on the normative foundations of the post-war international legal order in recent years. On the one hand, there is the view that international law embodies a distinctively universal, substantive, and independently captured moral order. Echoing the long tradition of natural law, this view argues that the role of international courts (hereafter, ICs) ultimately amounts to specifying this antecedent layer of reasoning. On the other hand, there is

Alain Zysset

alain.f.zysset@durham.ac.uk

1 Durham University, Durham, UK 
the view that, given reasonable disagreement over the content and limits of law, the basis for establishing the legitimate authority of international law is whether it can be justifiable to its ultimate subjects (individuals) construed as free and equal moral agents. Viewed through this lens, the role of international law and ICs is to help establish the conditions under which their primary subjects, namely states, can legitimately govern their own subjects, namely free and equal moral agents, without appealing to a comprehensive ethical view.

Two particular areas illustrate this distinction. In human rights theory (hereafter, HRT), the promoters of the so-called "moral," "ethical" or "orthodox" conception firmly bind the very purpose of HRT to the task of explaining what "human" means (Griffin 2008; Tasioulas 2015). Unsurprisingly, the defenders of this approach neither articulate the principled role nor reconstruct the actual practice of ICs (or domestic courts adjudicating international law). This is because, for the moral camp, human rights law (hereafter, HRL) embodies a distinctively universal status or value captured solely by substantive moral reasoning-one that explains what makes HRL distinct from its domestic analogue (constitutional law). In contrast, the political approach suggests that the role of HRLmore precisely the role of ICs or constitutional/supreme courts adjudicating HRL-is to operate a "test of public reason" (Kumm 2015) following Rawlsian principles of legitimacy (Rawls 1971). On this view, ICs play a crucial legitimacy-enhancing role that precisely excludes substantive moral reasoning to specify the appropriate content and limits of HRL.

In international criminal law theory (hereafter, ICLT), some argue that international crimes distinguish the class of wrongs that violate the status of "dignity" (Renzo 2012). Analogous to HRT, this status is identified solely by moral reasoning and not only determines the content and limits of international crimes but also derives the legitimate role of international criminal tribunals, as we shall see. In contrast to HRT, however, the principled and non-consequentialist role of (international) criminal tribunals of calling offenders to account-following Antony Duff's seminal account of criminal responsibility qua answerability - is clearly articulated. Unlike domestic trials, which embody the status of citizenship and its political-institutional community, international trials embody a moral-universal community to which offenders are called to account. The political camp, in turn, contends that the qualifying clauses of international crimes - the so-called "chapeaux" restricting the context of their commission (Haque 2012) — point to the particular role of state or state-like agents as the relevant class of (potential) perpetrators of international crimes and the distinctive responsibilities they hold as such. On this view, the relevant community of international crimes is a community of responsible states (Zysset 2016b).

This schematic distinction between the "moral" and the "political" suggests that across the multiple positive and analytical distinctions one can construct between HRL and ICL, the same normative frameworks are at play. Yet, a cross-examination of those fields remains notoriously absent from the predominant literature. What is more, this distinction has developed without paying close attention to the fast-developing practice of ICs and therefore to the question of the kind of reasoning (moral or political) to which those courts predominantly appeal. I suggest complementing the literature on those two fronts. First, how and to what extent do normative debates in HRT and ICLT mirror each other, and what does the mirror exactly reflect? Second, which of the two approaches best explains the practice of ICs? Paying more attention to judicial practice is based on two interrelated premises. On the one hand, given their growing caseload and the highly open-ended character of treaty provisions, ICs have progressively asserted their domain of authority. 
On the other hand, there is more and more evidence that ICs have played this lawspecifying role with little help from conventional (positivist) methods of international adjudication. The two premises converge in raising the question of legitimacy: Which normative considerations underpin the ICs' reasoning and what do those considerations change to their claim to legitimate authority?

This paper aims to remedy this deficit in three steps. In Sect. 2, I start by showing that the normative approaches outlined above (the moral and the political) transcend the conventionally distinct fields of HRT and ICLT. I explain in more detail to what the distinction analogously applies. Indeed, the distinction preserves the notions of rights and crime (e.g., an interest-based theory of rights for HRT or an "answerability" model of crimes for ICLT). Rather, the moral/political distinction concerns a sub-set of rights/ wrongs that is subject to an extra-territorial regime, that is, a regime that confers jurisdiction to ICs for the adjudication and/or enforcement of those norms. In this sense, "moral" and "political" concern the ultimate reasons for upholding this particular regime, rather than the archetypal function that those two bodies of law operate across the domestic/international divide. The moral relies on a distinctive values or status determined by substantive moral reasoning - a form of moral foundationalism, whereas the political points to the distinctive role of public authorities (states or state-like agents, domestic, or international) and the ethically neutral reasons those authorities should invoke to ground those norms, specify their content, and settle disputes.

It must be clear from the outset that I do not take a stand on which framework should ultimately prevail. Rather, I reconstruct two overarching conceptions that both have the resources to build a unifying account of international law. Then, in Sect. 3, I test those two approaches against selected practices of ICs. In the HRL context, I explore the proportionality test of the European Court of Human Rights (hereafter, the ECtHR). The ECtHR not only puts more weight on political freedoms (e.g., expression and reunion) over personal freedoms (e.g., privacy and religion)—most clearly, when those two groups of rights are in conflict in the proportionality test; it also relies on distinctively democratic considerations to justify the grounds, content, and limits of the prevailing rights and duties. In the ICL context, I examine how the International Criminal Court (hereafter, ICC) and Special Tribunals have defined the content and limits of the category of crimes against humanity. I show that ICs not only restrict this category to agents who exercise a state or state-like form of control or authority prior to (and that enables) the crimes; they also point in their reasoning to the distinctive role of political authorities as neutral guarantors of the basic security of their subjects. Both HRL and ICL seem therefore to deploy various aspects of the political approach.

Finally, in Sect. 4, I zoom out and articulate a specification of the political approach that can simultaneously illuminate the two practices. I contend that ICs offer reasons to their subjects (states and individuals) that help render the relation of authority between them legitimate in conditions of reasonable disagreement. I understand "legitimacy" as "a halfway along a spectrum between legal validity and justice: stronger than that of validity because it confers some moral authority upon a norm, but weaker than that of justice because reasonable people can disagree about the justness of a particular norm" (Sadurski 2015 , p. 404). The need for political equals to govern themselves despite reasonable disagreement is found at different stages of the political process. The practices of HRL and ICL capture only two basic stages of that kind. Treating subjects as political equals in the former case (HRL) requires grounding, defining, and limiting those rights based on their status of equal membership in their political community. Treating them on such terms in the latter case (ICL) requires not advancing a comprehensive view of what those norms 
(their violations) exactly attack but focuses on who can be liable for violations and who has jurisdiction over those criminal acts.

\section{The Moral/Political Divide in Human Rights Theory and International Criminal Law Theory}

The first step of the paper is to explain how the moral and the political approaches have structured the debate on the normative foundations of international law across the positive and conceptual specificities of HRL and ICL. Surprisingly, the two corresponding bodies of normative literature (HRT and ICLT) have been developing independently from each other (with a few notable exceptions, such as Renzo 2012). This may be due to regrettable intra-disciplinary boundaries within (the philosophy of) international law and political theory. Hence this section aims at showing that the moral and the political approaches similarly pervade the emerging fields of HRT and ICLT while similarly neglecting the role and practices of ICs. It thereby helps identify the challenges that the article subsequently tackles.

Suggesting a cross-examination of the debates in HRT and ICL supposes being clear on what can be cross-examined. Indeed, the moral and political approaches do not alter the underlying notions of right and crime that HRT and ICLT respectively specify. Following a broad Razian interest-based account of rights (Raz 1986; Tasioulas 2010), HRT aims to offer an (approximate) account of the distinctive interest(s) sufficient to hold others-in the particular case of HRL, all public authorities - to be under duties. While the specification of interest(s) and duty-holder(s) requires normative theorizing, the notion of rights itself remains stable. As Besson formulates, "the fundamental nature of the protected interests will have to be determined by reference to the context and time rather than established once and for all" (Besson 2012, p. 232). The moral/political distinction I construct hence intervenes only at this specification stage. Similarly, following a broadly Duffian account of criminal responsibility (Duff 2007), ICLT aims to account for to the distinctively public wrong(s) of ICL violations and to identify the relevant community in the name of which ICs can legitimately call wrongdoers to account. Further, "moral" and "political" do not alter the basic function of rights and crime either. The former defines the scope of individual freedoms vis-à-vis public authorities - a function already regulated by constitutional law. Similarly, ICLT preserves the criminal law's basic function of coercively intervening on behalf of individuals for committing publicly recognized wrongs - a function already regulated by domestic criminal law. Here again, what makes HRL and ICL distinctive is the extra-territorial dimension of their regime.

This article first aims to show that similar resources of philosophical theorizing-more precisely, a moral/political divide - are at play within those fixed conceptual and functional boundaries. More precisely, the moral approach fills the gap by appealing to a form of moral foundationalism. On this view, the legitimate authority of ICs is to a significant extent derivative of an independent and substantive elucidation of what those norms protect. It therefore concentrates on the right-holder. This elucidation may require radical reforms of the conventional lists of rights and crimes in international law. The political approach, in contrast, focuses on the principled role of public authorities and the conditions of their legitimate rule over individuals. This view is more attentive both to the preeminence of pluralism and disagreement in law and politics and to the fact that states hold primary responsibility for upholding those norms. It thereby focuses on the duty-holder. 


\subsection{Human Rights Theory}

Let me now explicate and illustrate the distinction in the context of HRT. The tenants of the moral approach, on the one hand, argue that the very point of a normative theory of human rights is to account for the claim that human rights are those rights we have just in virtue of being human. As Renzo states in a recent article, the moral approach is "primarily interested in the question of which important moral rights can be attributed to human beings simply in virtue of their human nature" (Renzo 2015, p. 128). One prominent example of that sort is Griffin's influential argument that human rights protect the capacity for normative agency (or "personhood"). As Griffin explains, "anyone who has the capacity to identify the good, whatever the extent of the capacity and whatever its sources, has what I mean by a conception of a worthwhile life; they have ideas, some of them reliable, about what makes a life better or worse" (Griffin 2008, p. 24). Griffin takes "human rights" as speaking for a distinctive and fundamental moral status-it fills a vacuum in our moral repertoire-whose elucidation requires substantive and independent moral reasoning. This is why Griffin almost exclusively focuses on the features of the right-holder - a concentration that has provoked the skepticism of rights theorists pointing to a neglect of correlative duties (Raz 2010; Tasioulas 2010; Besson 2012).

One implication of the moral approach is the derivative role of the law and the institutions (ICs or national courts) adjudicating HRL treaties and conventions. In Griffin's account, for instance, personhood is sufficient to derive the rights enshrined in "most of the conventional lists of human rights" (Griffin 2008, p. 33): life, prohibition of torture, security of person, political decision, free expression, assembly, free press, worship, education, and minimum provision. This being said, Griffin does consider the applicability of his abstract account. While acknowledging that personhood "is often not up to fixing anything approaching a determinate enough line for practice" (Griffin 2008, p. 37), he elaborates on "practicalities," which explain how personhood may be endangered under specific circumstances. Yet, this specification cannot precede the independent identification of personhood. The same is true of conflicts of rights: "virtually everyone would agree that an important part of their resolution comes by determining the degree of the values constitutive of personhood at stake" (Griffin 2008, p. 68). The independence of the moral approach vis-à-vis the law is well summarized by Tasioulas in a recent contribution: "human rights are to be identified by the use of natural reason, principally ordinary, truthoriented moral reasoning, as opposed to the artificial reason of some institution, such as law (...)" (Tasioulas 2015, p. 2).

The initial reaction of the political camp was not to argue that the project pursued by the moral camp is flawed per se, but that it does not help identify what is normatively salient about the emerging "global practice of human rights" (Beitz 2009, p. 134). Beitz, in particular, suggests that one ought to "understand the concept of human rights by asking for what kinds of actions, in what kinds of circumstances, human rights claims may be understood to give reasons" (Beitz 2009, pp. 7-8). Beitz then identifies a number of "paradigms of implementation" (Beitz 2009, pp. 33-40) that have constituted the core of the global practice of human rights before turning to the question of their normative force. Beitz, however, marks a radical shift from the moral approach in denying that the kind of independent moral reasoning à la Griffin is necessary to account for their normative practice. In Beitz' words, “there is no assumption a prior or independent layer of fundamental rights whose nature and content can be discovered independently of a consideration of the place of human rights in the international realm (...) (Beitz 2009, p. 102). This is due 
to the plurality of interests that human rights protect in practice and "it does not seem necessary to identify a list of relatively specific interests or values to serve as the grounds or subject-matters of human rights" (Beitz 2009, pp. 139-34).

In response, the moral camp has established (convincingly, in my view) that reconstructing the discursive function of human rights à la Beitz does not necessarily imply rejecting moral reasoning: if human rights are distinctive, as Beitz suggests, in that their violation pro tanto triggers some form of international concern [from coercive intervention to domestic contestation (Ibid., pp. 40-45)], it seems that it is part of such a political account to explain why some rights (their violation) and not others trigger such concern. This is the argument put forward by Renzo in a recent article: "if it is true that human rights play the special role that political theories attribute to them (be that of justifying political legitimacy, limiting state sovereignty, or triggering particular responses when violated), there must be something that explains why they can play this role" (Renzo 2015, p. 130). Put differently, it is not enough to identify the kind of action(s) that human rights trigger-which rights generate those responses-and claim that those responses do not fit the moral conception of human rights. However, to claim that moral reasoning is required is one thing. To assume that this reasoning amounts to the kind of moral reasoning $a$ la Griffin is another. I shall illustrate this point by reconstructing the reasons that HRL courts give for their judgments.

Before doing that, it is important to note that practice-focused theorists, such as Beitz, do not address HRL and ICs in great length either. Beitz, for instance, explicitly attaches human rights to a political rather than legal paradigm of implementation. In fact, the lack of legality explains why the emerging global human rights practice does not qualify as a "regime" in his view (Beitz 2009, p. 40). This view is flawed, in my view, because Beitz apprehends the practice in the absence of a global legal system of sanction and/or judicial review. As Besson rightly puts it, "very schematically, international law has been, alternatively and in a stark contrast, entirely assimilated either into ethics by international natural lawyers or into a sum of state interests by realist, postmodern, or voluntarist international lawyers" (Besson 2012, p. 214). In particular, regional and domestic forms of human rights adjudication, such as the developed systems of the Inter-American Court of Human Rights and of the ECtHR, are often mentioned but very rarely explored. In those contexts, a Beitzian approach to HRL would need to examine the distinctively legal actions that human rights trigger. Analogous to "international intervention" (Rawls 2001; Raz 2010) or "international concern" (Beitz 2009), the judgments of supranational courts induce national courts and domestic institutions to reform the legal order accordingly, to pay awards to victims, to initiate criminal proceedings, or even to re-open proceedings after the rendition of a judgment (Besson 2011; Huneeus 2013). I return to the legal practice in Sect. 3.

There is, however, an emerging political approach to HRL that applies to judicial practice specifically. Kumm has recently offered a sophisticated normative account of the proportionality test - the last step of constitutional and HRL review, when courts define legitimate grounds for interfering with rights-as establishing "a test of public reason" (Kumm 2015, p. 16) in order for both HRL but also constitutional courts to be conferred legitimate authority. Following Rawlsian tenets of political legitimacy, Kumm emphasizes "that human rights adjudicating courts are best understood as policing the boundaries of the reasonable, not the boundaries of justice. Participants of the democratic process should aspire to justice, but human rights courts do not review whether they succeed in that endeavour. The bar is set lower, by focusing merely on reasonableness understood as the justifiability in terms of public reason" (Kumm 2015, p. 20). That is why "[h]uman rights 
simultaneously stand above politics and are at the heart of the political process" (Kumm 2015 , p. 27). In conformity with Rawlsian premises, the reasons that ought to prevail in authoritative processes of law and politics should be neutral with respect to one's comprehensive account of the good (Rawls 1971). In this sense, Kumm's account illustrates the political view and the ethically neutral reasons that should be invoked to determine the content and scope of HRL. The political approach precisely excludes foundationalism à la Griffin.

\subsection{International Criminal Law Theory}

Let me now turn to the moral/political divide as it applies to ICLT. As already outlined, the underlying normative question here concerns the nature of the wrong of (international) crimes and the derived community to which perpetrators of those crimes ought to account. This debate hence endorses Duff's view that criminal responsibility implies calling the wrongdoer to account (i.e., to give reasons) to justify his conduct. This is responsibility as answerability. The wrongdoer is identified "not merely as an object of inquiry, but as subject, an agent who is called (through he cannot of course be forced) to take part in a rational process of proof and argument" (Duff 2007, p. 225). Therefore, to call to account implies assigning the wrongdoer a certain normative status-what Duff calls a "normatively laden description" (Duff 2007, p. 228). It follows that the institution of the criminal procedure is an artefact. Rather than embodying an independent moral view, it coerces in the name of a political community based on the terms to which we all have (hypothetically) consented. More precisely, Duff's account is premised on the category of citizenship. In this sense, Duff's own account illustrates the political approach. We are criminally answerable to our fellow citizens only to the extent that the wrongs committed fall within the terms of this artificial political community. As Duff puts it, "the law by which we are bound should not be one imposed on us by a sovereign: it should be a "common law"law which is our law, which speaks to us in our collective voice in terms of the values by which define ourselves as a polity" (Duff 2007, pp. 231-232).

Duff's accountability model allows him to avoid the problem of vigilantism with which other theories of criminal law [such as Luban's explicit adoption of "vigilante jurisdiction" in ICL (Luban 2004)] are concerned. If the criminal law is not relative to a particular normative community but simply follows the structure of moral wrongs across a variety of communities, then it is unclear why the state (or a state-derived entity in ICL) remains the exclusive jurisdiction. As Thorburn puts it, "we might be answerable to our private moral communities - friends and colleagues, religious communities, and social clubs—for certain wrongs we commit, but those private communities do not have the legitimate authority to impose coercive punishment on us for our wrongs in the same way the state routinely does through the criminal justice system" (Thorburn 2012, p. 86). Therefore, the criminal law is only concerned with public norms - "its proper concern is with the wrongs that we commit within that civic enterprise" (Duff 2007, p. 234). As I explain in Sect. 4, the same problem of vigilantism arises for the moral approach to ICL.

Now, the premise that the criminal law is not an institutional embodiment of the moral law erodes at the international level in Duff's view. This does not mean that the architecture of Duff's answerability model outlined earlier changes. Rather, the authorized jurisdictions of ICL (the ICC, Special Tribunals, or national courts applying through universal jurisdiction) are still viewed as institutional mechanisms to call wrongdoers to account. And wrongdoers are, again, called to account not just as objects of inquiry but as agents of reason and justification- "we respond to his wrongdoing, however terrible and 
'inhuman' it was, not by simply destroying him but by trying to bring him to answer for it" (Duff 2010, p. 604). Yet it remains unclear to which community perpetrators of international crimes should account. This is because the basic normative status posited at the domestic level, namely citizenship, does not naturally extend to the international level. There is little evidence that the rights, duties, and institutional structures that justify and realize citizenship exist beyond state boundaries. In Duff's terms,

An answer must show that the court acts in the name of some group to whom the defendant is answerable for its alleged crimes. It is not enough to argue that the wrongs he allegedly committed are terrible wrongs whose perpetrators ought to be punished: the trial's legitimacy depends upon the acceptability of the court's claim to act in the name of those who have the right to call the defendant to account. In whose name, then, can the ICC claim to act? (Duff 2010, p. 598)

This is precisely the question to which the moral and the political approaches provide distinct answers. Duff himself oscillates between the two. On the one hand, he contemplates the idea that the ICC embodies the institutions of the state in which the horrendous acts were committed. The reason for not fully endorsing this view, however, is that those institutions are missing precisely because of the consequences of the conflict and atrocities: "there might be doubt about whether there exists a political community to which the perpetrator could answer, on whose behalf the international court could claim to act" (Duff 2010, p. 599). On the other hand, Duff considers the view that the relevant community at the international level is humanity: "we can see the creation of the ICC as one of the ways in which the moral ideal of a human community might be given more determinate and effective institutional form (...)" (Duff 2010, p. 601).

With a view to develop the moral approach, Renzo has further developed the latter answer by offering a revisionist account of crimes against humanity (hereafter, CAH) (based on Article 7 of the Rome Statute). More specifically, Renzo argues that no element pertaining to legal structure should count as a necessary condition of CAH. As it stands, the definition of the Rome Statute requires that the constitutive acts meet two qualifying clauses. In addition to their particularly atrocious nature (16 major multiple offences including murder, extermination, enslavement, deportation, torture, rape, etc.), CAH must, first, be committed "as part of a widespread or systematic attack directed against any civilian population, with knowledge of the attack" (Art. 7(1)). The definition therefore requires that the crimes are not isolated offenses but form part of a large attack on a civilian population. Second, Art. 7(2)(a) specifies what drafters meant by "attack directed against any civilian population": "a course of conduct involving the multiple commission of acts referred to in paragraph 1 against any civilian population, pursuant to or in furtherance of a State or organizational policy to commit such attack". Those "chapeaux" are precisely taken to distinguish international crimes from domestic ones more generally (Haque 2012).

Now, Renzo argues that both clauses are not necessary to meet the threshold of CAH, because those clauses are not what make $\mathrm{CAH}$ normatively distinctive. Rather, Renzo answers the question of distinctiveness exclusively by examining one or the other constitutive acts of $\mathrm{CAH}$ (murder, rape, deportation, etc.) in isolation (hence separately from any legal or judicial qualification) and argues that each of those acts alone denies the "dignity" of human beings. Those acts are distinctive in that they show "a lack of respect and concern that we [individuals] owe to our fellow human beings qua human beings" (Renzo 2012, p. 456). While Renzo admits that he does not have a full-fledged account of "dignity," he heavily relies on recent work in HRT and endorses the view defended by the moral camp reviewed earlier. One radical implication of this revisionist project is that even 
ordinary and isolated acts of murder or rape should qualify and trigger the applicability of ICL (by national courts for practical reasons). Equipped with this independent account of the wrong of $\mathrm{CAH}$, Renzo returns to the question of community posed by Duff. To this question, Renzo contends that dignity creates a universal moral community to which violators are to be held accountable. CAH become "wrongs for which we are accountable to our fellow human beings in virtue of the membership in the wider community of humanity" (Renzo 2012, p. 456). This allows seeing that, although the core question of criminal responsibility remains stable-the identification of the relevant community of ICL - the moral approach deploys the same foundationalist approach as in HRT.

To conclude this section, I hope to have shown, first, that beyond the positive specificities of HRL and ICL as well as the conceptual features of right and crime, similar resources of normative theorizing are at play. More precisely, the moral approach consists in specifying, through substantive moral reasoning, the non-derivative status or value protected by HRL and ICL. My review of Renzo's account indicated that this approach to HRT can also inform the answer to the core normative question of ICLT. Yet, as Besson puts it (in the HRT context), "there is nothing in the inquiry into the justifications of human rights that necessarily implies foundationalism" (Besson 2014, p. 36). The political approach offers an entirely distinct framework: whether domestic or international, the normative criterion to determine the appropriate content and justification of both HRL and ICL should remain ethically neutral and hence justifiable from reasonably different views. Second, I have observed that the role and practice of ICs adjudicating HRL and ICL is quasi-absent from the normative literature. We have seen that Kumm does provide a principled (political) account for conducting the proportionality test in HRL, but does not put his account to the test by looking at the concrete practices of HRL. In the next section, I examine selected portions of international judicial practice with a view to testing the moral/political distinction.

\section{Incorporating the Practice of International Courts}

At this point, it is important to recall why examining judicial practices might be relevant for the purpose of this article. We have seen that the moral camp is particularly dismissive of those. The reasons are contingent but nonetheless serious. On the one hand, the growing (sometimes exponential, as in the case of the ECtHR) caseload of ICs in conjunction with to the open-ended character of treaty provisions implied that, from their inceptions, courts and tribunals of HRL and ICL have faced fierce normative choices. Is the prohibition against torture an absolute right? Does the right to free elections imply a right to referendum? The text of HRL treaties and conventions is irremediably vague. In the same vein, international tribunals have similarly specified the kinds of conduct that amount to international crimes. Can non-state agents commit crimes against humanity? Who counts as the "most responsible"? On the other hand, it is now widely accepted that HRL and ICL courts have addressed those questions without much help from conventional (positivist) theories of adjudication (Letsas 2010; Regan 2010). Those two premises converge in raising the question of legitimacy: which normative considerations underpin the ICs' reasoning and what do those normative considerations change to their claim to legitimate authority? In this section, I reconstruct how ICs have articulated the content and limits of some core provisions, and then test them against the moral/political distinction. 


\subsection{The ECtHR and Its Notion of "Democratic Society"}

Let me first zoom in on the "crown-jewel of the world's most advanced systems" (Helfer 2008, p. 125) of human rights protection, the ECtHR, which holds compulsory jurisdiction over 47 European states. I jump straight to a quite specific but decisive context of its adjudication, namely the proportionality test and, within that test, the last of step of balancing. In accordance with the text of the European Convention on Human Rights (hereafter, ECHR), the ECtHR must determine whether the interference found was nevertheless "necessary in a democratic society" (cf. Sadurski 2015). This test concerns in particular the derogable rights of the ECtHR, namely Articles 8-11 (privacy, thought and religion, expression, assembly). The balancing phase of the test is highly informative for my purpose, as it requires the ECtHR to determine the more precise content and limits of rights (in a notoriously short convention) against competing considerations and allocate a potential margin of appreciation to states. It should also be recalled that the Preamble to the ECtHR, unlike the Universal Declaration of Human Rights and its reference to "inherent dignity," does not refer to substantive foundations beyond "a common heritage of political traditions, ideals, freedom and the rule of law" (Preamble of the ECHR).

Does the ECtHR rely on moral or political considerations when striking the balance? I argue that the ECtHR has appealed to distinctively democratic considerations to define the content and limits of those rights - thereby specifying the political approach to HRT. Rather than confining the notion of "democratic society" to its formal aspect (the will of the majority), the ECtHR has articulated a substantive notion of democracy whose core tenet is the inclusion and traction of the interests and views of all subjects subjected to state authority. In so doing, the ECtHR might be viewed as acting in the name of the equal political status of individuals in their respective political community. This deliberative notion of democracy then helps the ECtHR sort out which rights, duties, and duty-holders should prevail (e.g., expression and reunion) in the proportionality test. Moreover, this notion helps explain why controversial provisions and obligations fall within the respondent state's jurisdiction. This justifies not scrutinizing certain provisions in depth (in particularly, privacy and religion, as we shall see), leaving it to the state to balance rights through a wide margin of appreciation.

Let me offer an overview of this distinction. With regard to Article 10 (expression), for instance, the ECtHR requires states not only to refrain from interfering with views and opinions expressed in the course of a public debate. It also demands-through positive obligations - that states promote contradictory and adversarial deliberations (on issues of public interest). Those views and opinions may deeply "offend, shock and disturb" (Handyside v. United Kingdom, para. 50). For instance, the ECtHR has derived "a right to be informed of plural perspectives" (Erdoğdu and Ince v. Turkey, para. 51) on issues of public interest. In both cases, the ECtHR holds that "such are the demands of pluralism, tolerance and broadmindedness without which there is no "democratic society" (Handyside v. United Kingdom, §50). This suggests that freedom of expression inheres in the distinctively political status conferred to individuals in a democratic society, and hence in the respect to the pluralism and profound disagreement that may arise in democratic processes. The ECtHR explicitly holds that "more generally, freedom of political debate is at the very core of the concept of a democratic society which prevails throughout the Convention" (Lingens v. Austria, para. 42).

The same emphasis applies to how the ECtHR understands Article 11 (reunion and association). The role devoted to political parties and the conditions of their dissolution are 
quite illustrative in this respect. Since pluralism and disagreement is at least as pervasive among individuals as among political parties, the sufficient conditions for dissolving a party should be stringent. In United Communist Party of Turkey and Others v. Turkey, in which the Turkish Communist Party was dissolved by Turkey's constitutional court, the ECtHR held that "there can be no justification for hindering a political group solely because it seeks to debate in public the situation of part of the State's population and to take part in the nation's political life in order to find, according to democratic rules, solutions capable of satisfying everyone concerned" (United Communist Party of Turkey and Others v. Turkey, para. 57). It emphasizes that a party should be dissolved only when the party in question has a real chance to seize power and endanger the democratic process itself once in office (notably by not respecting pluralism (Refah Partisi and Others $v$. Turkey, para. 87). Here again, the ECtHR relies on distinctively democratic considerations to set the more precise limits of derogable rights (see Zysset 2016a).

Yet, this predominant reasoning does not apply to all derogable rights. The ECtHR considers that delineating the precise contours of the right to private life (Article 8) and freedom of thought and religion (Article 9) fall outside its interpretive authority. It explicitly invokes the pervading disagreement among state parties over those rights' content and scope to justify its judicial restraint. For instance, the ECtHR has not (yet) specified what exactly constitutes a religious belief under Article 9. It notably held that "the question whether or not Scientology may be described as a 'religion' is a matter of controversy among the member States. It is clearly not the Court's task to decide in abstract whether or not a body of beliefs and related practices may be considered a 'religion' within the meaning of Article 9 of the Convention" (Kimlya and Others $v$. Russia, para. 79). As a result, those rights are more subject to a consensualist framework: the ECtHR screens practices at the national level and adjusts the level of protection based on the level of consensus among those practices. It is hence crucial to see the differential treatment between the two sets of rights: while the ECtHR adduces the content and fixes the limits of Article 10 and 11 by binding them to a normative notion of "democratic society", it defers the same exercise to state parties with regard to Article 8 and 9.

How can the moral/political distinction developed earlier help interpret the reasoning of the ECtHR? I suggest that the ECtHR is concerned with the distinctive role of public authorities of which this court is itself an instance. More precisely, it views those authorities as legitimate only if they equally address the interests of those subjects to its rule and justifies its decisions without appealing to a comprehensive ethical view of the applied norms. This view, as we have seen, has a particular resonance in the democratic context and the deliberative procedure that precedes the vote. The prevalence of pluralism and disagreement remains a core premise. In the words of Christiano, democrats "acknowledge fundamental conflicts of interests and convictions in society and assert that because of this lack of consensus, each person may demand an equal share in political rule" (Christiano 2003, p. 39). Democratic legitimacy therefore depends on tracking the opinions of all its subjects and this particularly concerns the treatment of minorities at the deliberative stage. In that sense, expressing views and opinions that "shock, disturb and divide," as the ECtHR calls it, contributes to the public justifiability of the democratic outcome and, consequently, to the legitimacy of the authority upholding it. As Christiano puts it, "the thought is that when an outcome is democratically chosen and some people disagree with the outcome, as some inevitably will, they still have a duty to go along with the decision because otherwise they would be treating the others unfairly" (Christiano 2013, Sect. 7). Conversely, while the ECtHR does minimally protect freedom of religion 
(e.g., the curtailment of worship places in Cyprus v. Turkey), it does not exercise authority beyond the overlapping consensus prevailing among its subjects.

\subsection{International Criminal Tribunals and The Notion of "Organization"}

Without much transition, let me turn to the practice of ICL. For the sake of concision, I restrict my investigation to the category of CAH. In the Rome Statute, $\mathrm{CAH}$ refers to 16 major and multiple offenses including murder, extermination, enslavement, deportation, torture, rape, etc. In addition, the definition comprises two "chapeaux," that is, qualifying clauses detailing the circumstances of the wrongful conduct. Analogous to the ECtHR and its "democratic society," the ICC adduces the content and limits of international crimes based on contextual considerations. Indeed, rather than exploring the acts constitutive of $\mathrm{CAH}$, ICs have explored the nature and capacities of the agent who commits the crime in order to circumscribe wrongful conduct and the enabling conditions that make international crimes distinct from domestic crimes.

As far as the contextual element of $\mathrm{CAH}$ is concerned (the requirement of a "widespread or systematic" attack preceding the crimes), the ICC held in the Bemba case that the attack must be "massive, frequent, carried out collectively with considerable seriousness and directed against a multiplicity of victims" (Prosecutor v. Jean-Pierre Bemba Gombo, para. 88). More importantly, it held that the attack must be "made by groups of persons who govern a specific territory or by any organization with the capability to commit a widespread or systematic attack against any civilian population" (Prosecutor v. JeanPierre Bemba Gombo, para. 83). This implies for the agent of $\mathrm{CAH}$ the ability to alter the condition of its subjects at will (including killing them) over a certain time period (before, during, and after the odious acts). This is in line with Darryl Robinson's suggestion that the " 'systematic' branch of the definition 'focuses not only on the organized nature of the activity but also on the character of the entity organizing it'" (Robinson 2011). Hence the perpetrator's identity-type is defined neither by its formal nature (state or non-state) nor limited to the capacity to commit a multiplicity of odious acts (murder, rape, deportation, enslavement, etc.) but by the capacity to control an entire territory (hence the people) on which the attack eventually occurs. This capacity clearly makes the agent of CAH akin to state or state-like authority.

The second clause of a "State or organizational policy" behind the attack has also been specified in judicial law based on the distinctive capacities of the agent. To determine whether a group qualifies as an organization within the meaning of Article (2)(a), the ICC held that it must determine "whether the group possesses, in fact, the means to carry out a widespread or systematic attack against a civilian population" (Situation in the Republic of Kenya, para. 90). This standard was also taken by the International Criminal Tribunal for the Former Yugoslavia (hereafter, ICTY) in Prosecutor v. Tadić, where the ad hoc tribunal held that "if the acts occur on a widespread or systematic basis [, then] that demonstrates a policy to commit those acts, whether formalized or not" (Prosecutor v. Dusko Tadić, para. 653). In addition, the ICTY made clear that the agent neither needs to be a state agent nor even a state-sponsored agent; it can just be tolerated by the state. The same tribunal also held in the Prosecutor $v$. Kordic case that the policy element does not need to be explicit or definite but that it remains an "important indicative factor" (Prosecutor v. Dario Kordić, para. 181-182).

In the more recent Kenya situation, the ICC held that the existence of a policy should still play a role and should be derived from a series of particular events including "the establishment and implementation of autonomous political structures at any level of 
authority in a given territory (...)" and "the establishment and implementation of autonomous military structures (...)" (Situation in the Republic of Kenya, para. 87). Here again, it appears that the class of agents who satisfy the clause is identified not only by the constitutive acts committed but by the wide range of coercive action(s) that it is capable to undertake on a given territory and its people. Consequently, the policy element can be simply inferred from the widespread and systematic test as an "improbability of coincidence" (Robinson 2013, pp. 9-10) As Robinson further explains, "the request for direct evidence of formal adoption of a policy is contrary to past jurisprudence, which consistently emphasizes that a policy need not be formally adopted and can be inferred from the manner in which the acts occur" (Robinson 2013, p. 13). This is also confirmed by Rodenhäuser in a recent study of the ICC's case law: "by interpreting the organizational requirement in its context, the chamber found that it is the capacities-meaning the means, resources, and co-ordination capabilities — of the group that are decisive" (Rodenhäuser 2014, p. 923).

The intermediate conclusion to be drawn is that if CAH do not necessarily imply a legally recognized state, it does imply a state or state-like authority. This conclusion does not overlook the basic premise that only individuals may be liable for ICL violations (e.g., Article 25 of the Rome Statue). In fact, recent research on individual liability for collective crimes precisely highlights the apparatus over which the perpetrator must exercise control (as part of the subjective element). In the words of Jain, "it is the person who occupies the central position in this collective part of the offence who is most interest to us, rather than the one who controls the individual micro offence" (Jain 2014, p. 141). But what makes this authority or control significant must come from a normative evaluation-this is where the normative theory of CAH matters. Can the moral/political distinction help interpret the tribunals' reasoning? Here again, the capacity-based account articulated above invites us to think about the legitimate role of state or state-like agents, and how the agent of CAH deeply and atrociously perverts this role. The core idea of "role inversion" has been brilliantly ascertained Luban (2004) and Vernon. Vernon for instance argues that the triad of "administrative capacity, local authority and territoriality" (Vernon 2002, p. 243) reveals the travesty of states when they attack their subjects: "when, therefore, they play an essential role in an attack on a group of a state's subjects, that group is absolutely worse off than it could be in the worst-case scenario of statelessness" (Vernon 2002, p. 243).

From the subjects' standpoint, however, if one just considers the odious acts without their enabling conditions, then the idea of role inversion loses its significance: "to be enslaved or tortured or killed by a state is not very different from suffering the same thing at the hands of a sadist or serial killer" (Vernon 2013, p. 230). We therefore need to more precisely explain where and how the perversion occurs from a subject's perspective (in addition to the odious acts, of course). I contend that what makes states normatively distinctive, from the subjects' standpoint, is that those subjects do not constantly need to evaluate the soundness of the state's actions and directives with regard to the basic domain of states' authority, namely territorial control and the monopoly on violence. This quality obtains by systematically issuing directives that help subjects better comply with the reasons that apply to them [according to Raz' concept of authority (Raz 2006)]. Viewing $\mathrm{CAH}$ through this lens more precisely reveals the extent to which the agent of CAH perverts the subjects' relation to political authority (Zysset 2016b). While the agent of CAH strikingly mirrors the systematic and pre-emptive role of the state, public authority is established to massively persecute, terrorize, and finally odiously attack subjects.

As explained in the Introduction, the moral/political distinction does not alter the underlying understanding of crime adopted throughout the paper (Duff's answerability 
model). It rather suggests different placeholders in this pre-established model. To recall, Duff's central question is the one of standing - that "the court acts in the name of some group to whom the defendant is answerable for its alleged crimes" (Duff 2010, p. 598). In refining the class of perpetrators of $\mathrm{CAH}$ as those agents holding the authoritative role of the state, I suggest a modified answer to the question of community. Surely, individuals remain the ultimate holders of normative value. But the kind of community at stake here is created by the duties that agents exercising state or state-like authority owe to their subjects just in virtue of the authority being exercised. The sole fact of holding a monopoly over territorial control and deploying large-scale coercive resources should serve the interest of their subjects in physical security. The class of perpetrators of CAH is therefore defined by the function of this authority, not its formal features (e.g., whether this authority is the official one).

\section{Conclusion: From Human Rights Law to International Criminal Law and Back}

I started this article with two neglected issues in the normative theory of international law. First, how and to what extent do normative debates in HRT and ICLT mirror each other, and what does the mirror exactly reflect? Second, which of the moral and political approaches best illuminates the practice of ICs? Having surveyed those limited practices and outlined how the political approach may best reconstruct it, I am now in a position offer a more abstract response to those two questions by bridging the two areas (HRT and ICLT) both theoretically and empirically. To recall, the key principle of the political view developed in this article is that the exercise of authority, in order to be conferred legitimacy, must equally serve the freedom and equality of its subjects without privileging a comprehensive ethical view of what (international) law precisely embodies. I suggest viewing international law as illustrating the second conception. In so doing, ICs subsidiarily act in the name of domestic authorities. It is legitimizing in furthering the public justifiability of public authority vis-à-vis individuals. As explained in the Introduction, it crucial to see that I adopt a basic Razian account of rights and a Duffian account of crime - that may be assessed on their own terms - and that my own contribution amounts to specifying those accounts in the more specific fields of HRT and ICLT and with reference to the practices reviewed.

In ICLT, it is by virtue of occupying (and perverting) a certain role-the exercise of public authority - that those agents become answerable to the international community for committing atrocious crimes. Rather than answering to humanity, I suggest viewing suspected perpetrators of $\mathrm{CAH}$ as answering to a community of responsible states. This political account of ICLT can then better explain why only state or state-derived agents (the ICC, Special Tribunals, national courts) can claim jurisdiction. In contrast, Luban develops the concept of "vigilante jurisdiction" (Luban 2004, p. 137) to extend the scope of the relevant jurisdiction to virtually any institutional structure that meets certain procedural criteria ("natural justice"). In contrast, my reconstruction of CAH coherently identifies the prosecuting entity to the entity being prosecuted. ICs subsidiarily take action on behalf of the failing state and thereby re-affirm their basic duties qua state or state-like authorities. When states in which $\mathrm{CAH}$ occur are unwilling or unable to prosecute and punish, the community of states calls its responsible members to account and organize an extra-territorial trial in the name of their common membership. I therefore suggest viewing 
extra-territorial jurisdiction as doing justice not only to the victims (by proving the crimes) but also to the accused perpetrator by treating him as responsible member of the normative community of states-in Duff's words, "we respond to his wrongdoing, however terrible and 'inhuman' it was, not by simply destroying him, but by trying to bring him to answer for it" (Duff 2010, p. 604).

In HRT, the interest sufficient to hold others (namely, public authorities) under a duty pertains to the individuals' equal political status in their political community. This status minimally requires addressing their equal say in the process of collective (democratic) deliberation. I have shown that the ECtHR emphasizes the rights, duties, and duty-bearers that are necessary for this process to unfold. The ECtHR's "democratic society" distinguishes those conditions that are "mutually justifiable" (Forst 2010) while leaving to the state a margin of appreciation when the question at hand reaches beyond an overlapping consensus. Here again, the authority held by this IC is justified in practice on distinctively political grounds. This allows foreseeing the common core between HRL and ICL: although each applies to a different stage of the political process, and despite that their operations differ, the normative grounds for upholding the two regimes are continuous; they have to do with the basic duties that public authorities (state or state-like) owe to their subjects as political equals. Clearly, this common core may justify other norms that fall outside the realm of HRL and ICL. HRL and ICL, I submit, form necessary conditions because they concern the threats that public authorities themselves pose to the basic freedom and equality of their subjects.

Acknowledgements I wish to thank the organizers of the "The Legitimate Ambit of Domestic and International Criminalization Conference" conference (Neha Jain and François Tanguay-Renaud) held at Osgoode Hall Law School (York University) in April 2016 where I first presented this paper. Neha and François also offered me tremendous comments that very much helped me to clarify my core claims of the paper. I am also very grateful to Darryl Robinson for offering detailed and insightful comments at the conference. Finally, I am indebted to Andreas Follesdal for continuously discussing this topic over the last year. Funding was provided by PluriCourts, University of Oslo (Grant No. 213400).

Open Access This article is distributed under the terms of the Creative Commons Attribution 4.0 International License (http://creativecommons.org/licenses/by/4.0/), which permits unrestricted use, distribution, and reproduction in any medium, provided you give appropriate credit to the original author(s) and the source, provide a link to the Creative Commons license, and indicate if changes were made.

\section{References}

Charles Beitz, The Idea of Human Rights (New York: Oxford University Press, 2009).

Samantha Besson, "The Erga Omnes Effect of the European Court of Human Rights," in La Cour européenne des droits de l'homme après le Protocole 14: premier bilan et Perspectives/The European Court of Human Rights after Protocol 14: Preliminary Assessment and Perspectives, ed. Samantha Besson (Schulthess, 2011), pp. 125-75.

Samantha Besson, "Human Rights: Ethical, Political ... or Legal? First Steps in a Legal Theory of Human Rights," in Donald Earl Childress III (ed.), The Role of Ethics in International Law (Cambridge: Cambridge University Press, 2012), pp. 211-45.

Samantha Besson, "Justifications," in Daniel Moeckli, Sangeeta Shah, and Sandesh Sivakumaran (eds.), International Human Rights Law (Oxford: Oxford University Press, 2014), pp. 34-52.

Thomas Christiano, "An Argument for Democratic Equality," in Thomas Christiano (ed.), Philosophy and Democracy: An Anthology (New York: Oxford University Press, 2003), pp. 39-68.

Thomas Christiano "Authority," The Stanford Encyclopedia of Philosophy (Spring 2013 Edition), Edward N. Zalta (ed.), available at: https://plato.stanford.edu/archives/spr2013/entries/authority/. 
Antony Duff, "Criminal Responsibility and Public Reason," in Michael Freeman and Ross Harrison (eds.), Law and Philosophy (Oxford: Oxford University Press, 2007), pp. 224-242.

Antony Duff, “Authority and Responsibility in International Criminal Law," in Samantha Besson and John Tasioulas (eds.), The Philosophy of International Law (New York: Oxford University Press, 2010), pp. 589-604.

Rainer Forst, "The Justification of Human Rights and the Basic Right to Justification: A Reflexive Approach," Ethics 120, no. 4 (2010): 711-40.

James Griffin, On Human Rights (New York: Oxford University Press, 2008).

Adil Ahmad Haque, "International Crime: in Context and in Contrast," in R.A. Duff, Lindsay Farmer, S.E. Marshall, Massimo Renzo, and Victor Tadros (eds.), The Structures of the Criminal Law (New York: Oxford University Press, 2012).

Larry Helfer, "Embeddedness as a Deep Structural Principle of the European Human Rights Regime," European Journal of International Law 19, no. 1 (2008): 125-59.

Alexandra Huneeus, "International Criminal Law by Other Means: The Quasi-Criminal Jurisdiction of the Human Rights Courts," American Journal of International Law 107, no. 1 (2013): 1-44.

Neha Jain, Perpetrators and Accessories in International Criminal Law: Individual Modes of Responsibility for Collective Crimes (London: Hart, 2014).

Mattias Kumm, "Human Rights and the Turn to Justification: On the Structure and Domain of Human Rights Practice” (2015), available at: http://www.law.nyu.edu/sites/default/files/upload_documents/ 2015KummHumanRightsProportionalityJustification.pdf.

George Letsas, “Strasbourg's Interpretive Ethic: Lessons for the International Lawyer,” European Journal of International Law 21, no. 3 (2010): 509-41.

David Luban, "A Theory of Crimes Against Humanity," Yale Journal of International Law 29, No. 1 (2004): 85-167.

John Rawls, A Theory of Justice (Cambridge: Harvard University Press, 1971).

John Rawls, The Law of Peoples (Cambridge: Harvard University Press, 2001).

Joseph Raz, The Morality of Freedom (Oxford: Clarendon Press, 1986).

Joseph Raz, "Human Rights without Foundations," in Samantha Besson and John Tasioulas (eds.), The Philosophy of International Law (New York: Oxford University Press, 2010), pp. 339-357.

Joseph Raz, "The Problem of Authority: Revisiting the Service Conception," Minnesota Law Review 90, no. 4 (2006): 1003-44.

Donald Regan, "International Adjudication: A Response to Paulus - Courts, Custom, Treaties, Regimes, and the WTO," in Samantha Besson and John Tasioulas (eds.), The Philosophy of International Law (New York: Oxford University Press, 2010), pp. 225-244.

Massimo Renzo, "Crimes Against Humanity and the Limits of International Criminal Law," Law and Philosophy 31, no. 4 (2012): 443-76.

Massimo Renzo, "Human Rights and the Priority of the Moral," Social Philosophy and Policy 32, no. 1 (2015): 127-48.

Darryl Robinson, "Crimes Against Humanity: A Better Policy on 'Policy"” online: (5 December 2013), Queen's University Legal Research Paper No. 2015-022, available at http://papers.ssrn.com/sol3/ papers.cfm?abstract_id=2364250.

Darryl Robinson, "Essence of Crimes against Humanity Raised by Challenges at ICC" (27 September 2011), EJIL: Talk! (blog), available at: http://www.ejiltalk.org/essence-of-crimes-againsthumanityraised-by-challenges-at-icc/.

Tilman Rodenhäuser, "Beyond State Crimes: Non-State Entities and Crimes against Humanity," Leiden Journal of International Law 27, no. 4 (2014): 913-28.

Wojciech Sadurski, "Supranational Public Reason: On Legitimacy of Supranational Norm-Producing Authorities," Global Constitutionalism 4, no. 03 (2015): 396-427.

John Tasioulas, "Taking Rights out of Human Rights," Ethics 120, no. 4 (2010): 647-78.

John Tasioulas, "On the Foundations of Human Rights," in Rowan Cruft, S. Matthew Liao, and Massimo Renzo (eds.), Philosophical Foundations of Human Rights (New York: Oxford University Press, 2015), pp. 45-70.

Malcolm Thorburn, "Constitutionalism and the Limits of the Criminal Law," in R.A. Duff, Lindsay Farmer, S.E. Marshall, Massimo Renzo, and Victor Tadros (eds.), The Structures of the Criminal Law (New York: Oxford University Press, 2012), pp. 85-105.

Richard Vernon, "What is Crime against Humanity?," Journal of Political Philosophy 10, no. 3 (2002): 231-49.

Richard Vernon, "Crime against Humanity: A Defence of the 'Subsidiarity' View," Canadian Journal of Law and Jurisprudence 26, no. 1 (2013): 229-40. 
Alain Zysset (a), "Searching for the Legitimacy of the European Court of Human Rights: The Neglected Role of 'Democratic Society," Global Constitutionalism 5, no. 1 (2016): 16-47.

Alain Zysset (b), "Refining the Structure and Revisiting the Relevant Jurisdiction of Crimes against Humanity," Canadian Journal of Law \& Jurisprudence 29, no. 1 (2016): 245-65.

Cases cited

Handyside v. United Kingdom, App. No. 5493/72, 7 December 1976.

Erdoğdu and Ince v. Turkey, App. Nos. 25067/94, 25068/94, 8 July 1999.

Lingens v. Austria, App. No 9815/82, 8 July 1986.

United Communist Party of Turkey and Others v. Turkey, App. No.19392/92, 30 January 1998.

Refah Partisi and Others (The Welfare Party) v. Turkey, App. Nos. 41340/98, 41342/98, 41343/98, 41344/98, 13 February 2003.

Kimlya and Others v. Russia, App. Nos. 76836/01, 32782/03, 1 March 2010.

Cyprus v. Turkey, App. No. 25781/94, 10 May 2001.

Prosecutor v Jean-Pierre Bemba Gombo, ICC-01/05-01/08, Decision on the Confirmation of the Charges (15 June 2009) (International Criminal Court, Pre-Trial Chamber).

Situation in the Republic of Kenya, ICC-01/09-19, Decision Pursuant to Article 15 of the Rome Statute on the Authorization of an Investigation into the Situation in the Republic of Kenya (31 March 2010) (International Criminal Court, Pre-Trial Chamber).

Prosecutor v. Dusko Tadić, IT-94-1-T, Opinion and Judgment (7 May 1997) (International Criminal Tribunal for the Former Yugoslavia, Trial Chamber).

Prosecutor v. Dario Kordić, IT-95-14/2-T, Judgment (26 February 2001) (International Criminal Tribunal for the Former Yugoslavia, Trial Chamber). 